\title{
Abhandlung
}

Raiko Krauß*, Lea Breuer, Simone Korolnik, Ernst Pernicka, Birgit Schorer, André Spatzier, Veronika Stein and Jörg Bofinger

\section{An Early Bronze Age Burial with a Golden Spiral Ring from Ammerbuch-Reusten, Southwestern Germany}

https://doi.org/10.1515/pz-2021-0010

Zusammenfassung: Eine bei Grabungen im Herbst 2020 nahe Ammerbuch-Reusten, Kreis Tübingen freigelegte Frauenbestattung der Frühbronzezeit weist starke Anklänge an das Bestattungsritual des Endneolithikums in Mitteleuropa auf. Als einzige Beigabe fand sich etwa in Hüfthöhe, links hinter der Bestattung ein kleines Spiralröllchen aus Golddraht, welches als bislang ältester, sicher datierter Edelmetallfund in Südwestdeutschland gelten kann. Der Fund fügt sich ein in eine überschaubare kleine Gruppe von Ringen aus Golddraht, die zu den ältesten Funden dieser Art in Mitteleuropa gehören. Seine Zusammensetzung mit ca. $20 \%$ Silber und weniger als 2\% Kupfer, sowie Spuren von Platin und Zinn verweist auf eine natürliche Goldlegierung, wie sie typisch ist für aus Flussseifen gewaschenes alluviales Gold. Das Spurenelementmuster ähnelt den sekundären Goldlagerstätten in Cornwall

\footnotetext{
*Corresponding author: Raiko Krauß, Institute of Prehistory, Early History and Medieval Archaeology, University of Tübingen, Germany. E-Mail: raiko.krauss@uni-tuebingen.de

Lea Breuer, Institute of Prehistory, Early History and

Medieval Archaeology, University of Tübingen, Germany.

E-Mail: le.breuer@student.uni-tuebingen.de

Simone Korolnik, Institute of Prehistory, Early History and

Medieval Archaeology, University of Tübingen, Germany.

E-Mail: simone.korolnik@uni-tuebingen.de

Ernst Pernicka, Curt-Engelhorn-Center Archaeometry, Mannheim, Germany. E-Mail: ernst.pernicka@ceza.de

Birgit Schorer, State Office for Cultural Heritage Management

Baden-Wuerttemberg, Esslingen am Neckar, Germany.

E-Mail: birgit.schorer@rps.bwl.de

André Spatzier, State Office for Cultural Heritage Management

Baden-Wuerttemberg, Esslingen am Neckar, Germany.

E-Mail: andre.spatzier@rps.bwl.de

Veronika Stein, Institute of Prehistory, Early History and

Medieval Archaeology, University of Tübingen, Germany.

E-Mail: veronika.stein@student.uni-tuebingen.de

Jörg Bofinger, State Office for Cultural Heritage Management Baden-

Wuerttemberg, Esslingen am Neckar, Germany.

E-Mail: joerg.bofinger@rps.bwl.de
}

und speziell aus dem Einzugsgebiet des Flusses Carnon. Die Bestattung fand sich unweit einer Gruppe weiterer Bestattungen der Frühbronzezeit und steht wahrscheinlich in einem Zusammenhang mit der bekannten Höhensiedlung auf dem nahegelegenen Reustener Kirchberg.

Schlüsselworte: Frühbronzezeit; Bestattung; Gold; Kupfer; Metallanalysen; Südwestdeutschland

Abstract: A women's burial of the Early Bronze Age that was uncovered near Ammerbuch-Reusten, Tübingen district in autumn 2020 shows clear relations to burial rites of the Final Neolithic in central Europe. The only grave good was in the rear of the burial. A small spiral ring made of gold wire at the left side of the burial at hip level, which can be considered to be the earliest securely dated precious metal find in southwestern Germany. The find fits into a small series of early spiral rings made of gold wire, which are among the oldest precious metal finds in central Europe. Its composition with c. $20 \%$ silver and less than $2 \%$ copper as well as traces of platinum and tin indicates the use of a naturally occurring gold alloy, most likely from so-called alluvial deposits obtained by panning from rivers. The trace element pattern strongly suggests that this type of gold derives from Cornwall, specifically from River Carnon. The burial matches a group of other burials from the Bronze Age on the plateau and is apparently related to a hilltop settlement on the nearby Kirchberg of Reusten.

Keywords: Early Bronze Age; Burial; Gold; Copper; Metall Analysis; Southwestern Germany

\section{Introduction}

As part of a cooperation between the Institute for Prehistory, Early History and Medieval Archaeology at the Tübingen University and the State Office for Cultural Heri- 

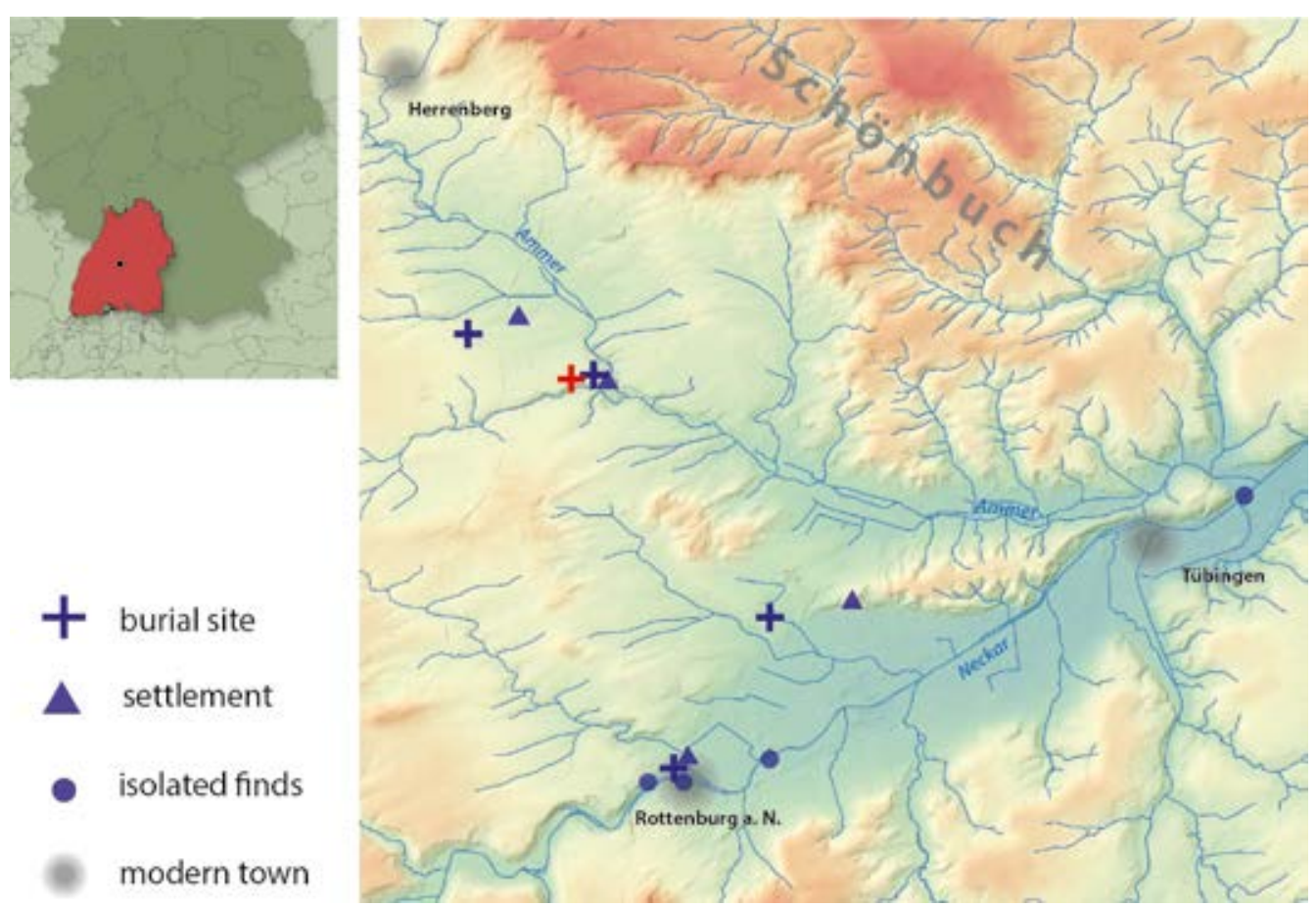

Fig. 1: Map of Bronze Age settlement landscape west of Tübingen. The red cross marks the burial from Reusten.

tage Management in Baden-Württemberg (LAD), a site near Ammerbuch-Reusten was examined from 21.09. to 09.10.2020, in a section of the land registry called "Grüninger". The site is located northwest of the village, near the "Kapf" hilltop, which allows a good panorama view westwards to Herrenberg and eastwards to Tübingen, bound in the north by the hill range of the Schönbuch, and in the south by the Suebian Jura.

The landscape on the plateaus west of Tübingen, known as "Oberes Gäu" is characterised by very fertile loess-loam soils and has been intensively used and populated since the Early Neolithic. In the extensive settlement area of "Stützbrunnen" between "Kapf" and "Grüninger" in the immediate hinterland of the prehistoric hilltop settlement on the Kirchberg of Reusten ${ }^{1}$, traces of settlement from the oldest Linearbandkeramik (LBK) to the Roman era can also be found ${ }^{2}$. From the site itself, finds from different phases of the Neolithic are known ${ }^{3}$. It is clear that the plateau has been used as a settlement area since the beginning of sedentarism. Remains from the LBK and the Middle Neolithic (Hinkelstein, Stichbandkeramik, Grossgartach and Rössen) known from the older find reports were confirmed by recent excavations.

1 Kimmig 1966.

2 Bofinger 2005; Hald 2009.

3 Albert/Schröter 1977; Bofinger 2005.
For many years, the LAD had been receiving reports from the volunteer representative Achim Lehmkuhl of human skeletal remains being ploughed out of two plots of land in the "Grüninger" field. During a brief emergency rescue intervention by Lehmkuhl in the year 2000, a crouched inhumation was partly uncovered. About $250 \mathrm{~m}$ further east, above a spring known as "Stützbrunnen", a small cemetery with 29 crouched burials, which can be classified as Early Bronze Age (EBA) on the basis of ${ }^{14} \mathrm{C}$ data, had already been uncovered in the same year, next to some Late Neolithic pits ${ }^{4}$. The grave uncovered during the 2020 campaign is evidently related to this burial ground. Numerous other finds of human bone fragments found on the farmland between the sites, triggered the current excavation campaign. The burial site thus fits into the EBA settlement landscape. It is characterized by a few other cemeteries and only a few known settlements (Fig. 1). Overall, the Bronze Age in the region must be regarded as comparatively poorly researched.

\section{The Bronze Age burial from Reusten}

During the excavation fragments of a human skull were found almost immediately on the surface, calling for extra

4 Bofinger/Hald 2001. 


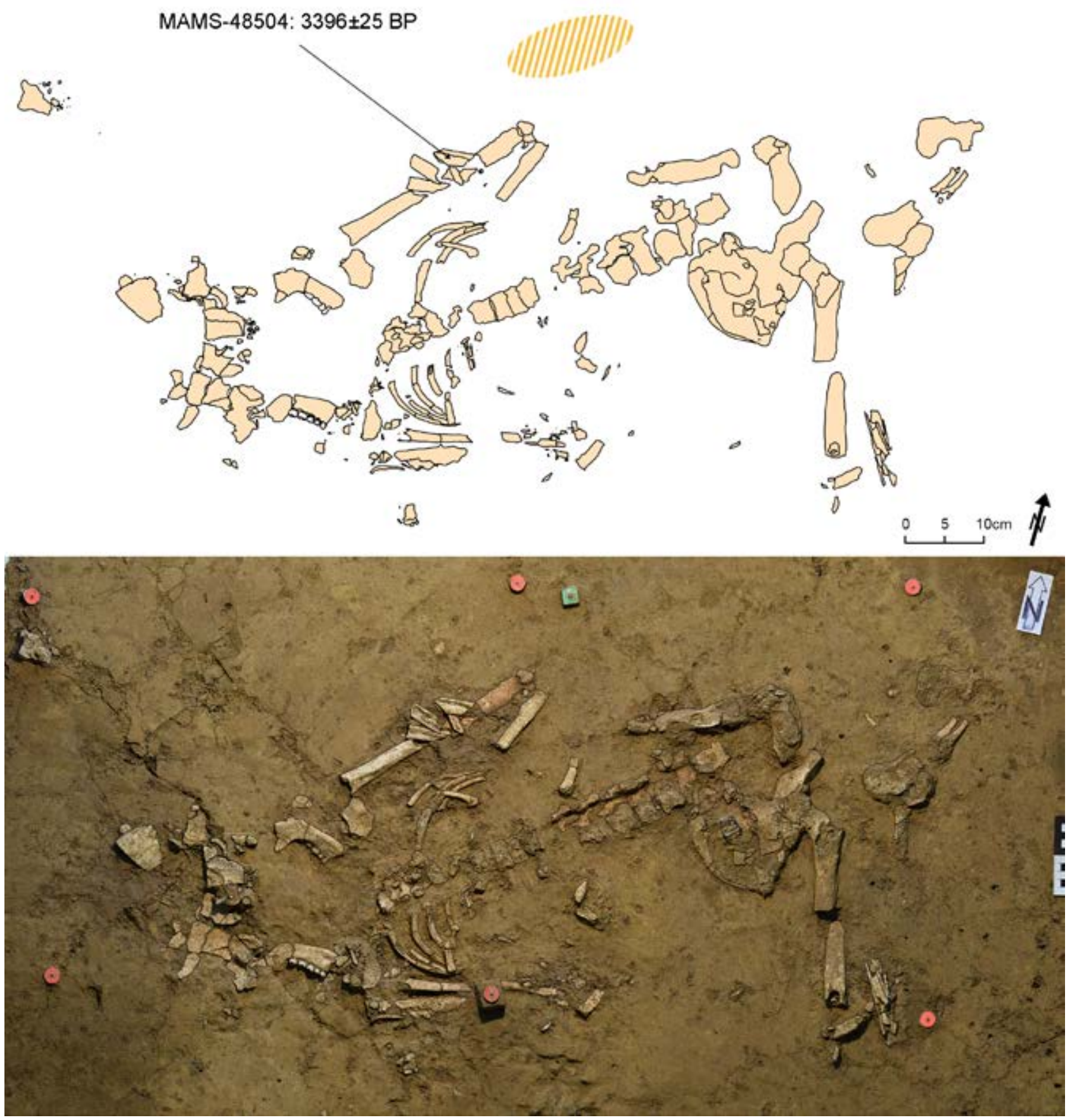

Fig. 2: Drawing and orthophoto of the excavated burial from Reusten. The yellow hatched area on the drawing and the green nail on the photo mark the location of the gold find.

care when digging. An inhumation burial was uncovered lying on the right with legs strongly bent at an approximate right angle to the lower body (Fig. 2).

The burial was oriented in a west-east direction, with the head in the west looking to the south. As soon as the top layers were removed, an ornament of wound gold wire appeared at the left side of the burial at hip level of the individual. For further investigation the sediment around the grave was dug laterally and the entire burial lifted en bloc, stabilized by wooden panels with polyurethane foam in the cavities. The excavation was then continued in the conservation laboratory. The earth was removed in four layers so that individual areas of the inhumation could be systematically recovered. Another half of a layer was necessary for the foot area. The bones were identified and assigned in situ, accordingly, marked on tags, recov- 


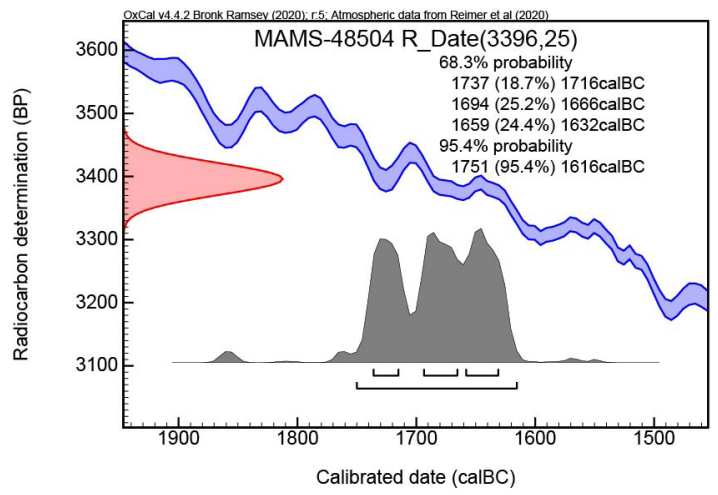

Fig. 3: Calibration of the radiocarbon date of the EBA burial from Reusten.

ered, laid out to dry and later packed in perforated PE bags. The badly degraded and thin left joint socket was dried in situ for several days and hardened using a $10 \%$ solution of Paraloid B-72 (ethyl methacrylate copolymer) in acetone. Only then did the removal from the soil take place. In parallel with the removal of the layers of earth, botanical remains and charcoal samples were also recovered. Their in-situ positions were mapped in two plans. The remains of the grave pit were only 5-7 cm deep. Therefore, it can be assumed that the original surface from which the grave was dug was at a much higher level than today's surface. The isolated location of the grave suggests that it was covered by a tumulus, of which no remaining traces could be detected, despite long sondage trenches.

It is noteworthy that neither the graves at the "Stützbrunnen" nor the burial uncovered in autumn 2020 showed remains of stone grave structures or traces of coffins. Both the EBA burial group of Gäufelden-Tailfingen and the graves of the small necropolis at Rottenburg had stone enclosures or stone bases for wooden coffins ${ }^{5}$.

The clearly west-east oriented posture of the skeleton in hocker position on its right side is characteristic for the final Neolithic Corded Ware (Schnurkeramik) in central Europe. Typically, the male and female burials of this period differ in orientation, the men with their heads lying in the west, the women with their heads in the east, whereby the skeleton generally faces south. In the southwest German EBA, however, north-south oriented hocker burials facing eastwards without strict gender dimorphism are also frequent ${ }^{6}$. Crouched burials in north-south alignment facing eastwards with males lying in the left side and females lying on the right side are characteristic for Final Neolithic

5 Reim 1997.

6 Lißner 2004.
Bell Beaker Culture. Clearly, the EBA groups adopted the burial customs of both Final Neolithic cultures, but disregarded their strict gender dimorphism.

A sample from the skeleton was commissioned to the Klaus Tschira laboratory in Mannheim for precise chronological age determination with radiocarbon. The result of sample MAMS- 48504 yielded an age of $3396 \pm 25 \mathrm{BP}$, which gave a calibrated (INTCAL20) dating interval of 1861-1616 calBC $(2 \sigma)$ and thus the grave belongs to the end of the EBA (Fig. 3).

The anthropological investigation identified the individual as female with an age range of 18 to 21 years. The remains were in a good condition and almost completely preserved, though various long bones and the skull were damaged due to agricultural activity. This hampered a metric analysis.

There was no evidence of pathological anomalies or traumata. The upper molar teeth (M2, M3) showed minor abrasion on the purchase area and some calculus. The estimated body height was around $1.60 \mathrm{~m}$.

\section{The gold ring}

The gold object found at the left side of the burial at hip level of the burial is a small ring made of doubly laid wire with a rectangular cross section (Fig. 4). This flat wire is bent into a spiral ring. The ring, which is not perfectly round, has an uneven diameter of $11.3-11.7 \mathrm{~mm}$. Its width is $5.1 \mathrm{~mm}$ and it weighs only $0.6 \mathrm{~g}$. The wire has a material thickness of $0.2 \mathrm{~mm}$ at one end, at the other end $0.1 \mathrm{~mm}$, on the loop $0.2 \mathrm{~mm}$ and in its central parts $0.2-0.3 \mathrm{~mm}$. The width of the wire is $0.7 \mathrm{~mm}$ at one end, at the other end $0.9 \mathrm{~mm}$, on the loop $0.6 \mathrm{~mm}$ and in its central parts $0.8-1.1 \mathrm{~mm}$.

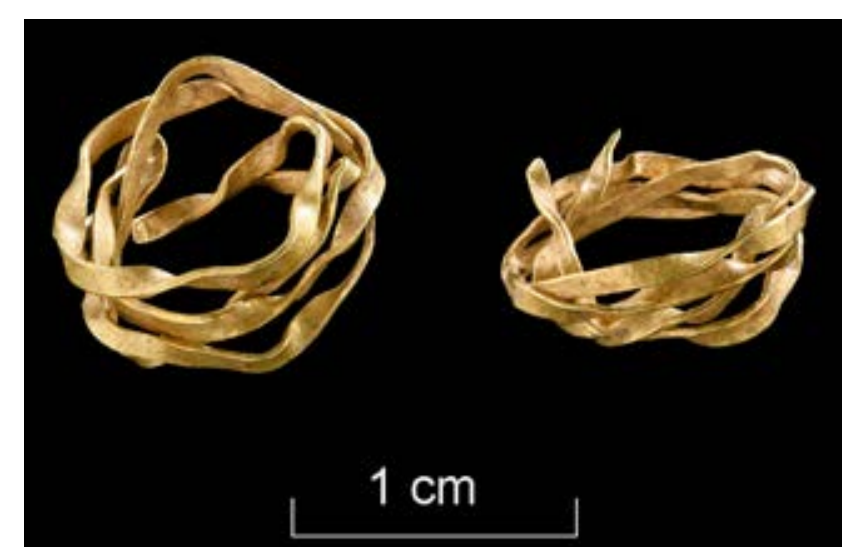

Fig. 4: Two views of the small gold ring (photo: Yvonne Mühleis, LAD Esslingen). 


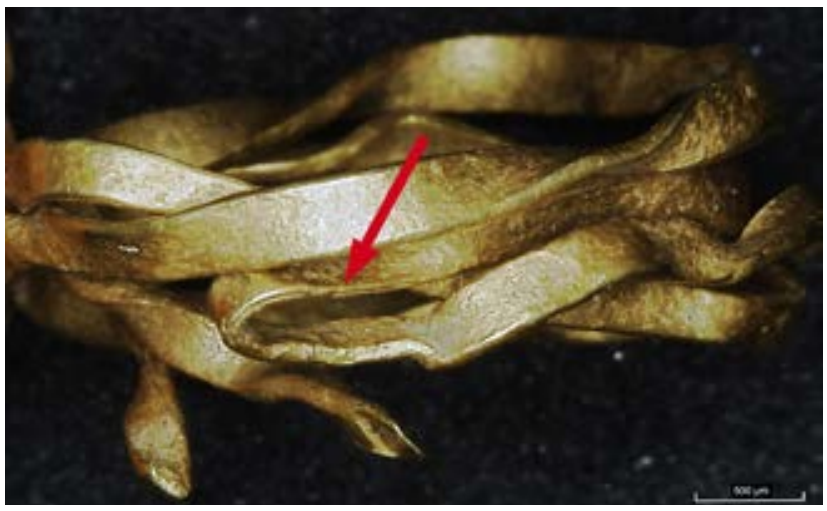

Fig. 5: Creases at the longitudinal edges as evidence of the flattening process of the wire

(microscope image: Christoph Berthold, CCA Tübingen).

The initial form must have been a hammered metal strip which was then folded in half and bent to a ring. Cutting such thin metal strips out of a sheet metal can be ruled out for the EBA. Such fine metal strips could only have been precisely cut with iron tools (Armbruster $2000,108)$. Furthermore, neither cutting marks nor traces of smoothing are visible. Rather, it is likely that the fine flat wire was formed with a non-cutting shaping technique. The basis was a pre-forged rod-shaped product that was probably pressed into a die with a groove. Simple die-shapes, made of hardwood for example, into which grooves have been cut, are suitable for this. As tools and utensils for the plastic deformation of gold, hammers and anvils made of stone and hardwood as well as bone and antler are possible for the $\mathrm{EBA}^{7}$. The final shape of the wire was created by flattening. The uneven width of the wire and the visible creases on the longitudinal edges caused by compression of the material are evidence of this (Fig. 5).

The wire used for the ring must have been approximately $6 \mathrm{~cm}$ in length. This wire was double-laid and wrapped twice around an underlying core. The uneven, not completely round shape of the ring indicates that this core must have been flexible. Bending around a soft core is also confirmed by the fact that the two strips of the double-laid wire are not evenly parallel to each other. At some parts the two strips turn in different directions (Fig. 6). This probably results from the fact that the wrapped material yielded differentially. This would be the case with textiles or a bundle of hair, for example.

The edges of the wire are rounded, very likely from usage, possibly from abrasion from hair or fabric. This

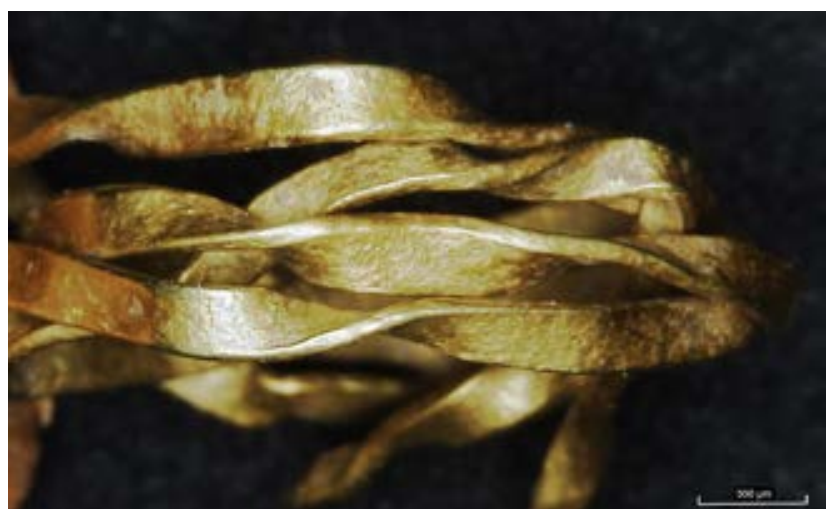

Fig. 6: The two strips twist differently (microscope image: Christoph Berthold, CCA Tübingen).

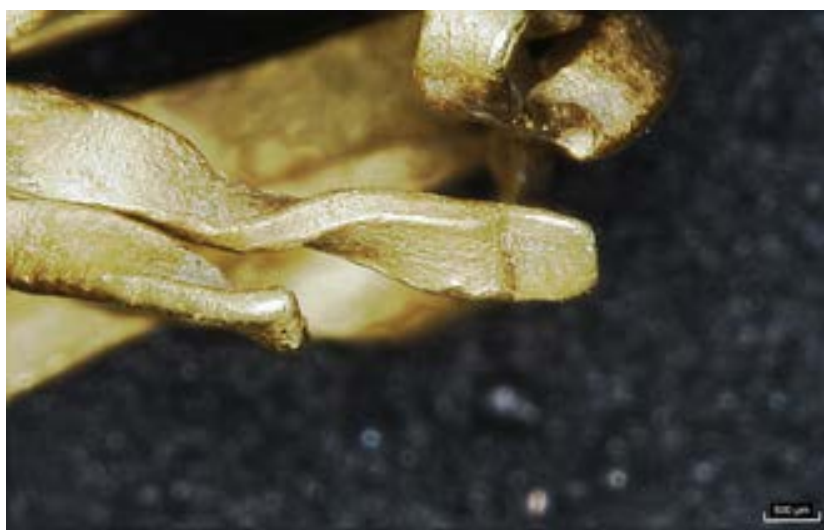

Fig. 7: The cut edge at one end shows clear traces of abrading (microscope image: Christoph Berthold, CCA Tübingen).

is particularly evident at one of the two ends. There is a visible edge from shortening the wire, probably from chiselling, which, however, has a clearly rounded appearance (Fig. 7). The ring was obviously worn; it did not find its way into the grave unused.

Small wire rings of gold are quite common in the Early to the Middle Bronze Age in central Europe and beyond. Similar rings made of a double-laid wire bent to a spiral ring are classified differently and described using various terminology, such as "Noppenringe", "Schleifenringe" or "Spiralringe" etc. ${ }^{8}$. They were mostly made from round wire and were obviously shaped, i.e. brought into their round shape, before they were added to the headdress. In the basic scheme the specimen from Reusten corresponds

8 e.g. Ruckdeschel 1978, 142-145; Neugebauer-Maresch/Neugebauer 1988/89, 123-126; Moucha 1997, 156-159; Meller 2014, 623-626.
7 e.g. Armbruster 2000, 47-56; 2012, 66-68; Bertemes 2004; Freudenberg 2009. 
Tab. 1: Chemical compositions and trace element patterns of the golden spiral ring.

\begin{tabular}{|c|c|c|c|c|c|c|c|c|c|c|c|}
\hline & \multicolumn{3}{|c|}{ Major elements [\%] } & \multicolumn{5}{|c|}{ Platinum group metals $[\mathrm{mg} / \mathrm{kg}]$} & & \multicolumn{2}{|c|}{$\begin{array}{l}\text { Trace elements } \\
{[\mathrm{mg} / \mathrm{kg}]}\end{array}$} \\
\hline Lab no. & $\mathrm{Au}$ & $\mathbf{A g}$ & $\mathrm{Cu}$ & $\mathbf{R u}$ & $\mathbf{R h}$ & $\mathbf{P d}$ & Os & Ir & Pt & $M n$ & $\mathrm{Fe}$ \\
\hline \multirow[t]{2}{*}{ MA-191849 } & 78.9 & 20.9 & 1.67 & $<0.1$ & 0.039 & 0.6 & $<1$ & 0.12 & 4.1 & 10.6 & 470 \\
\hline & \multicolumn{11}{|c|}{ Trace elements (continued) [mg/kg] } \\
\hline Lab no. & Co & $\mathbf{N i}$ & $\mathrm{Zn}$ & As & Se & Cd & Sn & Sb & $\mathrm{Te}$ & $\mathrm{Pb}$ & $\mathbf{B i}$ \\
\hline MA-191849 & 0.36 & 3.9 & 34 & 0.22 & $<2$ & 0.42 & 182 & 4.1 & 0.59 & 7.0 & 0.9 \\
\hline
\end{tabular}

to type 8 of Moucha9', a "Spiralring aus doppeltem Draht", i. e. a double-laid wire spiral ring. There are also very small, fine double-laid wire spiral rings from Bohemia for example, which have a diameter of less than one centimeter and a weight of less than $1 \mathrm{~g}$ and are comparable to the ring from Reusten ${ }^{10}$.

Functionally, such small rings are usually associated with hair accessories. This interpretation is supported primarily by their location in the head area of burials ${ }^{11}$. The location at the left side of the burial at hip level of the skeleton and the uneven shape can also be indications that the Reusten ring was worn in the hair, for example woven into a braid.

Unlike other EBA culture groups, such as the Unetice culture in central Germany, Bohemia and Bavaria ${ }^{12}$, or the Unterwölbling culture group in Austria ${ }^{13}$ for example, gold is extremely rare in the EBA of South Western Germany (Reim 1995, 3938). Only an Ösenkopfnadel from Mainz-Kastell and a gold bracelet, both dug out the Rhine without further information ${ }^{14}$ and an ensemble of an arm ring and wire spirals from Heidolheim (Alsace) are known ${ }^{15}$. Due to the lack of finding correlations for the both objects from Mainz, only a typological classification to the later EBA (Phase B according to the Reinecke system) is possible. In Alsace ten golden loop rings and one arm ring made of gold came from a depot but the circumstances of the find there are uncertain ${ }^{16}$. The arm ring shows great similarity to the ring from Helmsdorf in Saxony-Anhalt and is interpreted as an import from the central German region. The

9 1997, 157 Abb. 6.10:8; also Ruckdeschel 1978, Typ Gro.

10 Moucha 1997, 156.

11 Neugebauer-Maresch/Neugebauer 1988/89, 123.

12 Moucha 1997; Meller 2014.

13 Neugebauer-Maresch/Neugebauer 1989/90.

14 Schmid-Merkl 2016.

15 Meller 2014.

16 Gallay 1970. find spot is assigned to the South German EBA, but it is located on the other side of the Rhine on French territory.

All the more important is the traditional costume adornment of this inconspicuous gold wire ring in Reusten - simply a piece of wire that was wrapped around hair. It indicates the far-reaching relationships and increases the importance of this burial place.

Also noteworthy is a silver spiral ring from another female grave in the nearby Rottenburg burial ground. Also made from double-laid wire in a similar fashion to the ring from Reusten, but with a larger diameter and twisted ends as well as a carefully rounded shape ${ }^{17}$. Both raw materials, gold and silver, were difficult to obtain and are rare for the EBA population in the region of the Oberes Gäu and are therefore evidence of extensive contacts and probably also of a higher social status.

\section{Analysis of the gold}

The gold alloy of the ring from Reusten was analysed in the Curt-Engelhorn-Zentrum Archäometrie in Mannheim by laser ablation coupled with inductively-coupled plasma mass spectrometry (LA-ICP-MS). For experimental details see Lockhoff and Pernicka ${ }^{18}$. The results are given in Table 1.

The composition, with c. $20 \%$ silver and less than $2 \%$ copper as well as platinum and tin traces, indicates the use of a naturally occurring gold alloy, most likely from socalled alluvial deposits obtained by panning from rivers ${ }^{19}$. The copper content is marginally higher compared with most native gold, which usually contains less than $0.5 \%$ copper. The largest number of comparative analyses are

17 Reim 1995, 3938.

18 Lockhoff/Pernicka 2014).

19 Blet-Lemarquand et al. 2018, 113-115. 


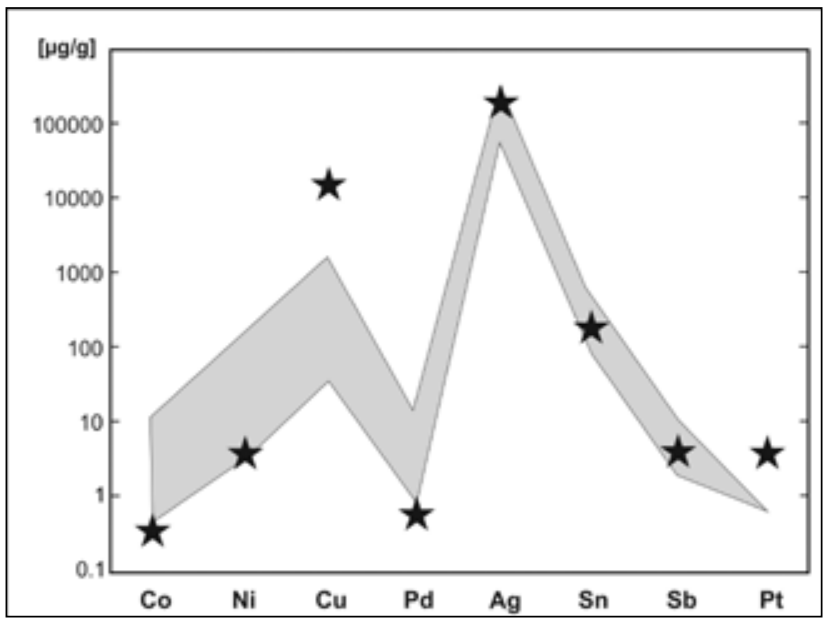

Fig. 8: Ranges of minor and trace element concentrations (median) of the Cornish gold occurrences from River Camon (grey field) in comparison with the gold ring from Reusten (stars).

still those published by Hartmann ${ }^{20}$. He defined compositional groups of prehistoric gold artefacts and studied their distribution in time and space. The composition of the gold ring from Reusten relates to Hartmann's group $\mathrm{A}_{3}$, predominantly found among EBA objects from the Carpathian basin as well as from central Europe though there in fewer numbers. Recently it has been discovered that this group can be further divided into: a smaller one, mainly distributed in central Europe, a larger and more variable one found mainly along the Danube in Hungary and Romania and, alloyed with copper, in Mycenae ${ }^{21}$. This type of gold is also associated with the Unětice culture, whose gold objects can be classified into two groups ${ }^{22}$, one of which resembles the above mentioned group $\mathrm{A}_{3}$ definded by Hartmann ${ }^{23}$. Unfortunately, tin was not detectable by the energy-dispersive X-ray fluorescence (EDXRF) analysis that was used in this study. The central European type of $\mathrm{A}_{3}$ gold was also used for the golden inlays on the Sky Disc of $\mathrm{Nebra}^{24}$. The suggestion that this type of gold could derive from southwest England ${ }^{25}$ was initially met with scepticism but was later substantially corroborated by Borg and Pernicka ${ }^{26}$ and Borg et al. ${ }^{27}$. If the Cornish provenance of this type of gold, specifically from River Carnon, can now

20 Hartmann 1970; 1982.

21 Borg 2010.

22 Frána 1997.

23 Hartmann 1970.

24 Lockhoff/Pernicka 2014.

25 Ehser et al. 2011.

26 Borg/Pernicka 2017.

27 Borg et al 2019. be considered as well established, then this also applies to the gold ring from Reusten, because its major and trace element pattern matches the gold from Cornwall very well (Fig. 8). Note that the concentration scale is logarithmic to accommodate the large range of concentrations over several orders of magnitude. There are some minor differences to the alluvial gold from the River Carnon. They can however be explained. Borg et al. ${ }^{28}$ documented that the native gold from the River Carnon is often intermixed with other minerals. Among those is also chalcopyrite $\left(\mathrm{CuFeS}_{2}\right)$. This would explain highly variable copper concentrations in artefact gold smelted from there. Furthermore, Lockhoff and Pernicka ${ }^{29}$ have pointed out that some elements such as platinum-group elements or even tin might be influenced by heavy minerals possibly panned together with the gold. This means that their concentrations in the gold artefacts are not necessarily fully comparable with the trace element pattern of the alluvial gold nuggets. Consequently, higher concentrations of these elements in the artefacts than in the natural gold are to be expected but not lower ones.

\section{The Bronze Age environment of the grave}

As mentioned above, the recently discovered EBA crouched inhumation is not an isolated phenomenon in this region. On the one hand, graves were uncovered in the immediate vicinity in the year 2000. On the other hand the Kirchberg, a hilltop site settled since the late Middle Neolithic, is located only $750 \mathrm{~m}$ towards the southeast of Reusten ${ }^{30}$. The most frequent are ceramics covering the whole time span of the EBA.

The graves of the small necropolis at the "Stützbrunnen", situated about 600 m northwest of the Kirchberg, were located in or below the ploughing horizon and as a result had already been massively disturbed. The original number of graves was certainly higher than the 29 burials identified and excavated ${ }^{31}$. All inhumations are crouched burials placed on the left and on the right side and mostly oriented west-east or southwest-northeast. Apparently, all age groups are represented. The absence of grave goods is striking; the only object recovered is a small, uncharacter-

\footnotetext{
28 Borg et al. 2019. 29 Lockhoff/Pernicka 2014. 30 Kimmig 1966. 31 Bofinger/Hald 2001.
} 


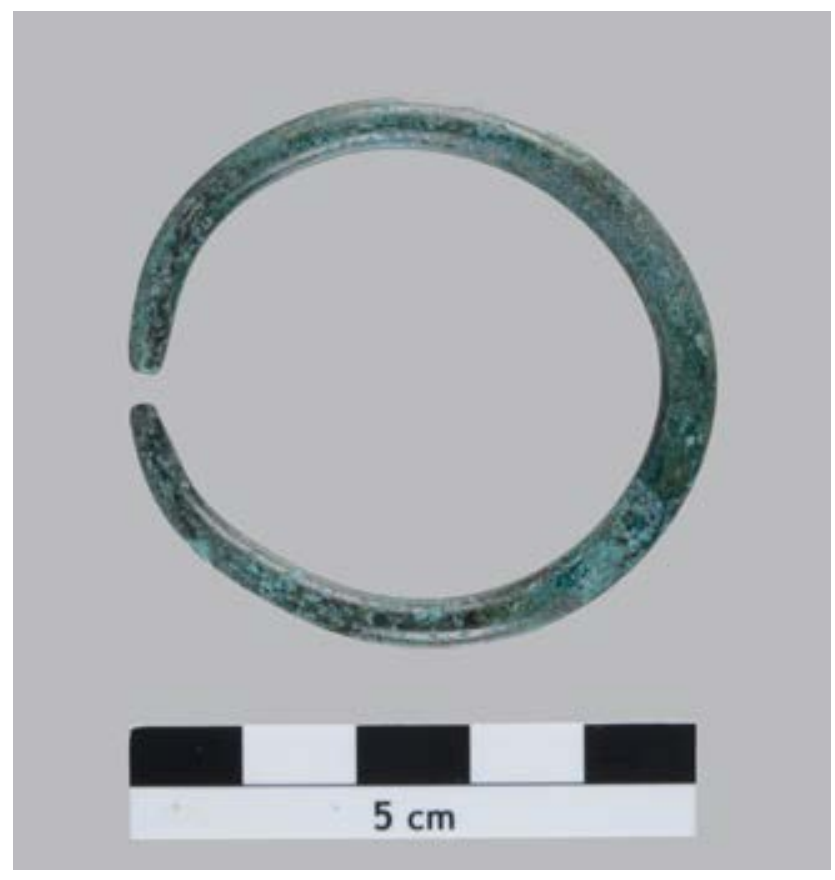

Fig. 9: Bronze arm ring from a child's grave at Reusten “Stützbrunnen”. (Photo: Hilde Jensen, University Tübingen).

istic bronze arm ring with a diameter of about $5 \mathrm{~cm}$ from a child's burials (Fig. 9).

The ring was analysed with energy-dispersive X-ray fluorescence (Table 2). It is regular tin bronze with a tin content of $11.7 \%$. Its trace element pattern strongly suggests a provenance of the copper from the Mitterberg region in the eastern $\mathrm{Alps}^{32}$. This type of copper became dominant in central Europe and even in the Nordic Bronze Age from the 16th century BC onwards ${ }^{33}$ and is thus consistent with the dating of the graves. Characteristic features are the roughly equal concentrations of arsenic and nickel with all other trace elements below $0.1 \%$, i. e. below the detection limit of the method used. A greenish patina on bone splinters from a second, almost completely destroyed grave indicates the presence of other metal objects, which, however, were not preserved.

A series of ${ }^{14} \mathrm{C}$ dates from human bones from several graves confirms that the cemetery dates to the younger EBA. Most dates fall in the same calibration range as the grave with the gold ring. Thus, this single grave and the Reusten necropolis belong to the same time horizon in the late phase of the EBA.

Thus the chronological evidence suggests that it is highly probable that the settlement on the nearby Kirch-

32 Pernicka et al. 2016.

33 Nørgaard et al. 2019.
Tab. 2: Chemical composition of the bronze ring; all values are given in mass \%. Concentrations of $\mathrm{Co}, \mathrm{Zn}, \mathrm{Se}, \mathrm{Ag}, \mathrm{Sb}, \mathrm{Te}, \mathrm{Au}, \mathrm{Pb}, \mathrm{Bi}$ were sought but were below $0.1 \%$.

\begin{tabular}{llllll}
\hline Lab no. & $\mathrm{Cu}$ & $\mathrm{Fe}$ & $\mathrm{Ni}$ & As & Sn \\
\hline MA-194338 & 76 & 0.06 & 0.58 & 0.56 & 11.7 \\
\hline
\end{tabular}

berg belongs to the land use pattern of the EBA. An extensive number of ceramic finds documents an important settlement site at the transition from the Early to the Middle Bronze Age $^{34}$. It is one of the few cases in southern Germany where a burial ground and a settlement can be related to each other.

Only a few graves of the EBA are known from the wider environs of the site: In the landscape of the Neckar and Ammer valleys between Rottenburg a. N. and Herrenberg, for example, only three other burial sites of this period have been identified with certainty.

In Gäufelden-Tailfingen, in the district of Böblingen, about 750 m north-east of the village, three Early Bronze Age graves were excavated in 1977/78 when a road was rerouted $^{35}$. This site is situated about $2.6 \mathrm{~km}$ northwest of the Early Bronze Age cemetery of Reusten. Graves 1 and 2 were double burials, in grave 3 only one body was buried. A copper flat-head needle, some small bronze spiral rollers and typical bone beads date the small burial group to the EBA.

In Rottenburg-Wurmlingen an isolated EBA Burial was discovered in $1983^{36}$.

About $7.3 \mathrm{~km}$ south-southeast of Reusten, a small necropolis with 10 graves and 13 burials of the EBA was uncovered in 1991 on the north-eastern outskirts of Rottenburg a. N. ${ }^{37}$. The majority of the burials are dated to the advanced phase of the EBA, at least one grave seems to have been created towards the end of the EBA. According to some ${ }^{14} \mathrm{C}$ data, the graves from Rottenburg are about 200 years younger than the grave finds from the Nordstadtterrasse in Singen im Hegau (distr. Konstanz) and date from about 1980 to $1880 \mathrm{BC}$.

Thus, the Reusten grave fits well into a regional distribution of finds from the EBA. Although likely locally rooted in Final Neolithic traditions regarding burials customs, the find of a gold ring indicates contacts to Western Europe. Particularly the origin of the gold variety from southern England makes these references clearly tangible. However,

34 Kimmig 1966.

35 Berz/Schlipf 1984, $611 \mathrm{ff}$.

36 Krause 1988.

37 Reim 1997. 
in the EBA copper was already supplied from the nearer deposits in the Austrian Alps, whereas the provenance of the added tin remains uncertain. Since EBA finds of precious metals are extremely rare in South Western Germany and while bronze predominates in funerary and deposition contexts, the gold of the Reusten grave points towards far reaching contacts related to luxury objects. This find is of outstanding importance for the region as it is the first EBA and thus the earliest gold find with a clear and well dated context from South Western Germany.

\section{Acknowledgements}

We would like to thank the landowner, Jürgen Rothfuss for permitting and supporting our field research, and the excavations, the German Research Foundation (DFG) and the State of Baden-Württemberg for financial support, and the local authorities from the municipality of Ammerbuch for their help. Dr. Arno Patzelt and his Team from Terrana Geophysik led the geophysical survey work. Dr. Marc Heise from the LAD for technical assistance. We also would like to thank Dr. Christoph Berthold at the Competence Center Archaeometry Baden-Wuerttemberg (University of Tübingen) for supporting the optical investigations and to Dipl. Arch. Nicole Lockhoff for the LA-ICP-MS analysis of the gold ring. The excavation was carried out by archaeology students of the University of Tübingen, namely Sophie Anders, Robin Andrews, Georgi Dankov, "Golden” Hannah Huber (the lucky one who found the gold ring), Anna Koch, Kathleen Schaupp, Jonas Sprißler and Shana Wernado. We would especially like to thank David Bibby for correcting the English manuscript.

\section{Bibliography}

Albert/Schröter 1977: S. Albert/P. Schröter, Mittel- und Jungneolithische Gruben von Ammerbuch-Reusten, Kreis Tübingen. Fundberichte Baden-Württemberg 3, 1977, 80-106.

Armbruster 2000: B. Armbruster, Goldschmiedekunst und Bronzetechnik. Studien zum Metallhandwerk der Atlantischen Bronzezeit auf der Iberischen Halbinsel. Monographies Instrumentum 15 (Montagnac 2000).

- 2012: -, Feinschmiedewerkzeuge vom Beginn der Metallurgie bis in die Römische Kaiserzeit. In: A. Pesch/R. Blankenfeldt (Eds.), Goldsmith Mysteries. Archaeological, pictorial and documentary evidence from the 1st millenium AD in northern Europe. Schriften des Archäologischen Landesmuseums, Ergänzungsreihe 8 (Neumünster 2012) 59-85.

Bertemes 2004: F. Bertemes, Frühe Metallurgen in der Spätkupferund Frühbronzezeit. In: H. Meller (Ed.), Der geschmiedete
Himmel. Die weite Welt im Herzen Europas vor 3600 Jahren (Stuttgart 2004) 144-149.

Berz/Schlipf 1984: G. Berz/Th. Schlipf, Gäufelden, Tailfingen (Kreis Böblingen). Fundberichte Baden-Württemberg 9, 1984, 611-612.

Blet-Lemarquand et al. 2018: M. Blet-Lemarquand/H. da Mota/ B. Gratuze/V. Leusch/R. Schwab, Material Sciences applied to West Hallstatt gold. In: R. Schwab/P.-Y. Milcent/B. Armbruster/ E. Pernicka (Eds.), Iron Age Gold in Celtic Europe. Society, Technology and Archaeometry. Proceedings of the International Congress held in Toulouse, France, 11-14 March 2015. Forschungen zur Archäometrie und Altertumswissenschaft 6,1 (Rahden/Westfalen 2018) 101-132.

Bofinger 2005: J. Bofinger, Untersuchungen zur neolithischen Besiedlungsgeschichte des Oberen Gäus. Materialhefte Archäologie Baden-Württemberg 68 (Stuttgart 2005).

-/Hald 2001: -/J. Hald, Siedlungsreste der Michelsberger Kultur und älterbronzezeitliche Gräber? Archäologische Untersuchungen am „Stützbrunnen“ bei Ammerbuch-Reusten, Kreis Tübingen. Archäologische Ausgrabungen in BadenWürttemberg 2000, 2001, 35-38.

Borg 2010: G. Borg, Warum in die Ferne schweifen? Geochemische Fakten und geologische Forschungsansätze zu Europas Goldvorkommen und zur Herkunft des Nebra-Goldes. In: H. Meller/ F. Bertemes (Eds.), Der Griff nach den Sternen. Wie Europas Eliten zu Macht und Reichtum kamen. Internationales Symposium in Halle (Saale) 16.-21. Februar 2005. Tagungen des Landesmuseums für Vorgeschichte Halle 5/II (Halle/Saale 2010) 735-750.

-/Pernicka 2017: -/E. Pernicka, Goldene Zeiten? - Europäische Goldvorkommen und ihr Bezug zur Himmelsscheibe von Nebra. Jahresschrift für mitteldeutsche Vorgeschichte 96, 2017, 111-138.

- et al. 2019: -/-/A. Ehser/N. Lockhoff/G.S. Camm/C.V. Smale, From distant lands - provenance studies of natural gold in comparison to the gold of the Sky Disc of Nebra. In: H. Meller/ F. Bertemes (Eds.), Der Aufbruch zu Neuen Horizonten. Neue Sichtweisen über die Europäische Frühbronzezeit. Abschlusstagung der Forschergruppe FOR 550 vom 26.-29. November 2010 in Halle (Saale). Tagungen des Landesmuseums für Vorgeschichte Halle 19 (Halle/Saale 2019) 55-78.

Ehser et al. 2011: A. Ehser/G. Borg/E. Pernicka, Provenance of the gold of the Early Bronze Age Nebra Sky Disk, central Germany: geochemical characterization of natural gold from Cornwall. European Journal Mineralogy 23,6, 2011, 895-910.

Frána 1997: J. Frána, Materialzusammensetzung. In: G. Lehrberger/ J. Friedrich/R. Gebhard/J. Hrala (Eds.), Das archäologische Gold in Bayern, Böhmen und Mähren. Památky archeologické, Supplementum 7 (Praha 1997) 189-190.

Freudenberg 2009: M. Freudenberg, Steingeräte zur Metallbearbeitung - Einige neue Aspekte zum spätneolithischen und frühbronzezeitlichen Metallhandwerk vor dem Hintergrund des Schleswig-Holsteinischen Fundmaterials. Archäologisches Korrespondenzblatt 3, 2009, 1-20.

Gallay 1970: M. Gallay, Die Besiedlung der südlichen Oberrheinebene in Neolithikum und Frühbronzezeit. Badische Fundberichte Sonderheft 12 (Freiburg 1970).

Hald 2009: J. Hald, Die Eisenzeit im Oberen Gäu. Materialhefte Archäologie Baden-Württemberg 86 (Stuttgart 2009). 
Hartmann 1970: A. Hartmann, Prähistorische Goldfunde aus Europa. Studien zu den Anfängen der Metallurgie 3 (Berlin 1970).

- 1982: -, Prähistorische Goldfunde aus Europa II. Studien zu den Anfängen der Metallurgie 5 (Berlin 1982).

Kimmig 1966: W. Kimmig, Der Kirchberg bei Reusten. Eine Höhensiedlung aus vorgeschichtlicher Zeit (Stuttgart 1966).

Krause 1988: R. Krause, Der Beginn der Metallzeiten. In: D. Plank (Ed.), Archäologie in Württemberg. Ergebnisse und Perspektiven der archäologischen Forschung von der Altsteinzeit bis zur Neuzeit. Festschr. zum 25jährigen Gründungsjubiläum der Gesellschaft für Vor- und Frühgeschichte in Württemberg und Hohenzollern (Stuttgart 1988) 111-139.

Lißner 2004: B. Lißner, Zu den frühbronzezeitlichen Gruppen in Süddeutschland. Leipziger online-Beiträge zur Ur- und Frühgeschichtlichen Archäologie 13, 2004, 1-20.

Lockhoff/Pernicka 2014: N. Lockhoff/E. Pernicka, Archaeometallurgical investigations of Early Bronze Age gold artefacts from central Germany including gold from the Nebra hoard. In: H. Meller/R. Risch/E. Pernicka (Eds.), Metals of power - Early gold and silver. 6th Archaeological Conference of Central Germany October 17-19, 2013 in Halle (Saale). Tagungen des Landesmuseums für Vorgeschichte Halle 11/I (Halle/Saale 2014) 223-235.

Meller 2014: H. Meller, Die neolithischen und bronzezeitlichen Goldfunde Mitteldeutschlands - Eine Übersicht. In: H. Meller/ R. Risch/E. Pernicka (Eds.), Metalle der Macht - Frühes Gold und Silber. 6. Mitteldeutscher Archäologentag vom 17. bis 19. Oktober 2013 in Halle (Saale). Tagungen des Landesmuseums für Vorgeschichte Halle 11 (Halle/Saale 2014) 611-716.
Moucha 1997: V. Moucha, Gold der frühen Bronzezeit. In: G. Lehrberger/J. Fridrich/R. Gebhard/J. Hrala (Eds.), Das Prähistorische Gold in Bayern, Böhmen und Mähren: Herkunft - Technologie - Funde. Pamatky Archeologicke, Supplementum 7 (Prag 1997) 154-164.

Neugebauer-Maresch/Neugebauer 1988/89: C. NeugebauerMaresch/J.-W. Neugebauer, Goldobjekte aus den Frühbronzezeitnekropolen Franzhausen I und Gemeinlebarn F. Mitteilungen der Anthropologischen Gesellschaft in Wien 118/119, 1988/89, 101-134.

Nørgaard et al. 2019: H.W. Nørgaard/E. Pernicka/H. Vandkilde, On the trail of Scandinavia's early metallurgy: Provenance, transfer and mixing. PLoS ONE 14,7, 2019, 1-32.

Pernicka et al. 2016: E. Pernicka/J. Lutz/Th. Stöllner, Bronze Age Copper Produced at Mitterberg, Austria, and its Distribution. Archaeologia Austriaca 100, 2016, 19-55.

Reim 1995: H. Reim, Frühes Edelmetall in Süddeutschland. Galvanotechnik 86,12, 1995, 3936-3940.

- 1997: -, Frühbronzezeitliche Gräber und Funde im Neckartal um Rottenburg. In: Archäologisches Landesmuseum BadenWürttemberg (Ed.), Goldene Jahrhunderte. Die Bronzezeit in Südwestdeutschland. ALManch 2, 1997, 98-101.

Ruckdeschel 1978: W. Ruckdeschel, Die frühbronzezeitlichen Gräber Südbayerns. Ein Beitrag zur Kenntnis der Straubinger Kultur. Antiquas, Reihe 2, Abhandlungen aus dem Gebiete der Vorund Frühgeschichte 11 (Bonn 1978).

Schmid-Merkl 2016: C. Schmid-Merkl, Der Oberrhein. Archäologie einer metallzeitlichen Flusslandschaft. Materialhefte zur Archäologie in Baden-Württemberg 103 (Darmstadt 2016). 